\title{
The beta cell glucokinase promoter variant is an unlikely risk factor for diabetes mellitus
}

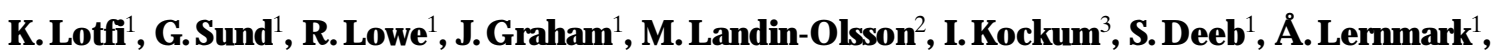 \\ the D iabetes Incidence Study in Sweden (DISS)*

\footnotetext{
${ }^{1}$ Departments of Medicine, Biostatistics and Genetics, University of Washington, Seattle, Washington, USA

${ }^{2}$ Department of Medicine, Lund University Hospital, Lund, Sweden
} \\ ${ }^{3}$ Department of Molecular Medicine, The Clinical Genetics Unit, Karolinska Hospital, Stockholm, Sweden
}

Summary Glucokinase plays an important role in the regulation of insulin secretion and is therefore an attractive candidate gene for both insulin dependent (IDDM) and non-insulin-dependent (NIDDM) diabetes mellitus. A single G-A nucleotide polymorphism at the -30 position of the beta-cell specific promoter region of the glucokinase gene was previously associated with reduced beta-cell function. In the present study we analysed 268 consecutive newly diagnosed Swedish patients classified with either IDDM $(n=205)$, NIDDM $(n=31)$ or unclassifiable $(n=32)$ diabetes between the ages of 15 and 35 years along with a group of 158 age- and sex-matched control subjects. The beta-cell promoter region was amplified by the polymerase chain reaction and the
G-A variant identified by single strand conformational polymorphism. There was no significant difference in allele frequencies of $\mathrm{G}$ and $\mathrm{A}$ between any of the subject groups and likewise, no significant difference in the frequencies of the G/G, G/A, or A/A genotypes. Eight subjects were homozygous for the less common A allele, five had IDDM and three were control subjects. Our results suggest that the -30 beta-cell glucokinase promoter variant is not associated with IDDM. [Diabetologia (1997) 40: 959-962)

Keywords IDDM, NIDDM, glucokinase gene, polymerase chain reaction, single strand conformational polymorphism, islet cell antibodies, GAD65 antibodies.
Glucokinase [EC 2.7.1.1] is proposed to be the glucose sensor and metabolic signal generator in pancreatic beta cells [1]. It is a rate-limiting enzyme in glycolysis and seems to play a major role in regulating insulin secretion. The glucokinase gene has 12 exons. Exons 2 to 10 are transcribed in both the liver and the pancreatic islets; however, exon 1 transcribed in the liver is different from that transcribed in the islets [2]. Mutations in the coding region of the glucokinase

Received: 3 February 1997 and in revised form: 29 April 1997

The first two authors contributed equally to this study. Corresponding author: Professor A. Lernmark, University of Washington, Department of Medicine, Box 357710, Robert H. Williams Laboratory, Seattle, WA 98195, USA

A bbreviations: GCK, Glucokinase; IDDM, insulin-dependent diabetes mellitus; NIDDM, non-insulin-dependent diabetes mellitus; PCR, polymerase chain reaction; SSCP, single strand conformational polymorphism; ICA, islet cell antibodies; bp, base pair gene have been demonstrated to be responsible, in some patients, for mature-onset diabetes of the young (MODY); however, these mutations have been found in less than $1 \%$ of patients with the more common form of non-insulin-dependent diabetes mellitus (NIDDM) [3, 4]. There is no evidence that the MODY type of glucokinase (MODY 2) mutations are a risk factor for insulin-dependent diabetes mellitus (IDDM) [5]. However, transcription is controlled by two promoter regions, an upstream promoter which is active in beta cells and a downstream promoter active in hepatocytes [2]. In genome wide searches the glucokinase gene on chromosome $7 p$ has been proposed as a candidate locus $[5,6]$. It is therefore possible that genes controlling beta-cell phenotypes may confer susceptibility to IDDM.

Because of its role in the regulation of insulin secretion, the glucokinase gene is an attractive candidate gene for both IDDM and NIDDM. Previous studies have found associations between a simple 
sequence repeat polymorphism located approximately 10 kilobases $(\mathrm{kb}) 3^{\prime}$ of the human glucokinase gene and NIDDM in American blacks [7], Mauritian Creoles [8] and Japanese [9]. More recently, a single G-A substitution at position -30 of the beta-cell specific promoter of the glucokinase gene has been reported in Japanese-Americans [10], French [4], African-Americans [11], and Caucasian Americans [3]. Since beta-cell function was reduced in subjects with the -30 beta-cell glucokinase gene promoter variant [10], the aim of the present study was to determine the beta-cell glucokinase promoter polymorphism in a population-based study of Swedish 15-35-year-old, new-onset and consecutively diagnosed diabetic and control subjects [12]. It was hypothesized that the variant single nucleotide substitution would be associated with diabetes in this particular age group.

\section{Subjects and methods}

Subjects. Since 1983, all newly diagnosed Swedish diabetic patients, 15-34 years of age, have been registered by the Diabetes Incidence Study registry in Sweden (DISS) [12,13]. Genomic DNA was extracted from peripheral blood leukocytes. In this study, DNA was available from 268 diabetic and 158 healthy control subjects who were selected from the Swedish population register to match the patients on the basis of age and gender, but not place of residence (Table 1 ). The patients were diagnosed in 1987-1988 and represent randomly selected subjects from a large registry of consecutively diagnosed diabetic patients in Sweden [14]. The patients were classified according to standard World Health Organization (WHO) criteria for IDDM and NIDDM. Unclassifiable patients are reported as unclassified.

D etection of the glucokinase beta-cell promoter polymorphism. The presence of the G-A substitution was identified [15] by single-strand conformational polymorphism (SSCP) analysis [16]. A 177-base pair (bp) fragment of the 3' region of the promoter was amplified by polymerase chain reaction (PCR) using genomic DNA as a template. PCR primers were: primer beta 2-5' (CAA GGC GAT TGA GTG GTC ACC ATG) and primer beta 2-3' (GAC TGT GTC TCT CAC ATC CTA GCC). PCR was performed in $10-\mu l$ reactions containing $10 \mathrm{ng}$ DNA, $1 \mu \mathrm{l} 10 \mathrm{X}$ reaction buffer (Perkin Elmer, Foster City, CA, USA), $125 \mu \mathrm{mol} / 1 \mathrm{dNTP}, 0.5 \mu \mathrm{mol} / 1 \mathrm{l}$ of each primer, $0.5 \mathrm{U}$ Taq DNA polymerase (Perkin Elmer), and $1.0 \mu \mathrm{Ci}$ P-32 dCTP (NEN Dupont, Boston, MA, USA). PCR amplification consisted of $3 \mathrm{~min}$ at $94^{\circ} \mathrm{C}, 34$ cycles of $30 \mathrm{~s}$ at $94^{\circ} \mathrm{C}$ and $1 \mathrm{~min}$ at $72^{\circ} \mathrm{C}$, and 1 cycle of $3 \mathrm{~min}$ at $94^{\circ} \mathrm{C}$. A $5-\mu \mathrm{l}$ sample of PCR product was diluted in $95 \mu \mathrm{l} 0.1 \%$ SDS with $10 \mathrm{mmol} / \mathrm{l}$ EDTA. Diluted DNA product $(5 \mu \mathrm{l})$ was added to $5 \mu \mathrm{l}$ of Stop Mix ( $90 \%$ Formamid, 20 mmol/l EDTA, $0.15 \%$ Bromphenol Blue, and $0.15 \%$ Xylene Cyanol). The diluted samples were denatured for $3 \mathrm{~min}$ at $94^{\circ} \mathrm{C}$ and then plunged onto ice. Single-stranded fragments were electrophoresed in a $5 \%$ polyacrylamide gel containing $10 \%(\mathrm{vol} / \mathrm{vol})$ glycerol at $75 \mathrm{~W}$ for $5 \mathrm{~h}$ at $39^{\circ} \mathrm{C}$. The gels were dried and then autoradiographed for $40 \mathrm{~h}$. The (SSCP) analysis allows an unambiguous detection of the G-A substitution [15]. The films were scored by two independent observers.

H L A typing and islet cell autoantibodies (ICA ). HLA genotyping of these patients was carried out as described elsewhere
Table 1. Patients and controls in the Swedish Diabetes Incidence Study analysed for the glucokinase gene beta-cell specific promoter variant

\begin{tabular}{lccll}
\hline Subjects & $\mathrm{n}$ & $\begin{array}{l}\text { female/ } \\
\text { male }\end{array}$ & $\begin{array}{l}\text { Median } \\
\text { age (years) }\end{array}$ & $\begin{array}{l}\text { Age } \\
\text { range }\end{array}$ \\
\hline Control subjects & 158 & $72 / 86$ & 24.9 & $15-35$ \\
All patients & 268 & $113 / 155$ & 25.0 & $15-35$ \\
IDDM & 205 & $82 / 123$ & 25.0 & $15-34$ \\
NIDDM & 31 & $16 / 15$ & 29.5 & $19-35$ \\
Unclassified & 32 & $15 / 17$ & 28.0 & $18-35$ \\
\hline
\end{tabular}

$[17,18]$. ICA were determined by indirect immunofluoresence as previously reported [12]. GAD65Ab were determined in a radioligand binding assay $[19,20]$. Our laboratory participated in the ICA and GAD65 Ab workshops and proficiency testing (100\% specificity and $100 \%$ sensitivity in the 1996 serum exchange).

Statistical analysis. Associations between allelic and genotypic frequencies in control subjects and diabetic patients were tested with a chi square test with Yate's correction where needed. Fisher's exact test was used when the expected number of alleles or genotypes in either the patient or control groups was less than 5 under the null hypothesis of no association. A logistic regression analysis was also used to compare genotype frequencies in IDDM patients and healthy control subjects. In addition, associations between the glucokinase gene polymorphism and HLA, ICA and GAD65 antibodies were also assessed with Chi-square tests. When such tests were inappropriate due to sparse contingency tables, exact permutational tests [21] were used instead.

\section{Results}

Allele frequencies of $\mathrm{G}$ and $\mathrm{A}$ for control subjects as well as patients with IDDM, NIDDM and unclassifiable diabetes are shown in Table 2. The allele frequencies of $\mathrm{G}$ varied between 84 and $86 \%$ in the different subject groups while the frequencies of A varied between 14 and $16 \%$. Consequently there was no appreciable difference in allele frequency between any of the subject groups. Moreover, the gene frequencies of $\mathrm{G} / \mathrm{G}, \mathrm{G} / \mathrm{A}$, and $\mathrm{A} / \mathrm{A}$ revealed no difference between any of the subject groups. The genotype distribution by gender in the control group also showed no difference between males and females (data not shown).

Of the subjects studied, 241 were male and 185 were female. There was a significant gender difference in the IDDM patients (123 males and $82 \mathrm{fe}$ males); however, no significant difference in genotype $(\mathrm{G} / \mathrm{G}, \mathrm{G} / \mathrm{A}$, or $\mathrm{A} / \mathrm{A})$ frequency between males and females was detected between age groups 1520 years, $21-25$ years, $26-30$ years, and $31-35$ years (Table 3). Of the subjects studied, only eight (four males and four females) were found to be homozygous for the less common A variant. Five of these eight had IDDM while three were control subjects. 
Table 2. Allele and gene frequencies at the glucokinase gene beta-cell specific promoter variant

\begin{tabular}{lrlllll}
\hline & \multicolumn{2}{l}{ Allele frequency } & & \multicolumn{3}{l}{ Gene frequency } \\
\cline { 2 - 3 } & $\mathrm{G}$ & $\mathrm{A}$ & & $\mathrm{G} / \mathrm{G}$ & $\mathrm{G} / \mathrm{A}$ & $\mathrm{A} / \mathrm{A}$ \\
& $\mathrm{n}(\%)$ & $\mathrm{n}(\%)$ & & $\mathrm{n}(\%)$ & $\mathrm{n}(\%)$ & $\mathrm{n}(\%)$ \\
\hline Control subjects & $268(85)$ & $48(15)$ & & $113(71)$ & $42(27)$ & $3(2)$ \\
All patients & $460(86)$ & $76(14)$ & & $197(73)$ & $66(25)$ & $5(2)$ \\
IDDM & $353(86)$ & $57(14)$ & & $153(75)$ & $47(23)$ & $5(2)$ \\
NIDDM & $52(84)$ & $10(16)$ & & $21(68)$ & $10(32)$ & $0(0)$ \\
Unclassified & $55(86)$ & $9(14)$ & & $23(72)$ & $9(28)$ & $0(0)$ \\
\hline
\end{tabular}

Table 3. Male and female gene frequencies in IDDM patients

\begin{tabular}{lcccccl}
\hline \multicolumn{7}{c}{ Age at diagnosis (years) } \\
\cline { 3 - 7 } & & $15-20$ & $21-25$ & $26-30$ & $31-35$ & All \\
& & $\mathrm{n}(\%)$ & $\mathrm{n}(\%)$ & $\mathrm{n}(\%)$ & $\mathrm{n}(\%)$ & $\mathrm{n}(\%)$ \\
\hline Male & G/G & $27(66)$ & $25(76)$ & $26(81)$ & $11(65)$ & $89(72)$ \\
& G/A & $12(29)$ & $7(21)$ & $6(19)$ & $5(29)$ & $30(25)$ \\
& A/A & $2(5)$ & $1(3)$ & $0(0)$ & $1(6)$ & $4(3)$ \\
Female & G/G & $17(74)$ & $21(75)$ & $18(95)$ & $8(67)$ & $64(78)$ \\
& G/A & $6(26)$ & $7(25)$ & $0(0)$ & $4(33)$ & $17(21)$ \\
& A/A & $0(0)$ & $0(0)$ & $1(5)$ & $0(0)$ & $1(1)$ \\
\hline
\end{tabular}

Logistic regression analysis was used to compare genotype frequencies in IDDM patients with the healthy control subjects. Since some of the controls were matched to IDDM patients on the basis of age, gender and region, attempts were made to adjust for these partially matched variables in the regression. There was no statistical evidence of association between the glucokinase polymorphism and IDDM either a) ignoring the effects of HLA-DQ $(p=0.78)$, or $b)$ after adjusting for the effects of HLA-DQ $(p=0.58)$. Finally, analysis of contingency tables showed that neither ICA positivity $(p>0.62)$, ICA levels (Juvenile Diabetes foundation units) $(p>0.89)$, nor GAD65Ab positivity $(p>0.76)$ was associated with the glucokinase gene beta-cell promoter variant.

\section{Discussion}

A recent study has suggested that a G-A polymorphism at the -30 position of the beta-cell specific glucokinase promoter region is associated with glucose tolerance in Japanese-American subjects with impaired glucose tolerance [10]. This study excludes association in the Swedish population of this single base pair variant with diabetes in 15-35-year-olds, whether classified with IDDM or NIDDM.

The patients and control subjects studied represent a group of individuals from a homogeneous population. Although it was not possible to analyse all of the patients in the DISS investigation [12], the control and IDDM patients were well matched.
Therefore, it is possible for us to conclude that the beta-cell specific promoter variant does not represent a genetic risk factor for IDDM in Swedish 15-35year-olds. The number of NIDDM $(n=31)$ and unclassified $(n=32)$ subjects studied was small however. The classification of these patients was further complicated by the possibility that some of these patients in fact represented slow-onset IDDM patients; 6 of 31 (19\% ) NIDDM and 14 of 32 (44\%) unclassifiable patients had ICA. Nevertheless reclassification of these individuals to the IDDM group did not change the frequency of the glucokinase promoter genotypes. Since diabetes is difficult to classify in this age it is not possible to make a definite conclusion about the association of the promoter variant with NIDDM.

Mutations in the coding region of the glucokinase gene have been associated with MODY in approximately $60 \%$ of French and other families with a history of MODY [22, 23]. However, these mutations account for less than $1 \%$ of the more prevalent form of NIDDM. More importantly, it was observed that the G-A variant at the -30 position in the beta-cell specific glucokinase promoter was associated with reduced beta-cell function in Japanese-American men [10]. This variant has also been shown to be more prevalent in individuals with IGT than in NIDDM patients in a Finnish population [24].

It was observed that the G-A variant was associated with a major decrease in promoter activity in vitro [25]. Although the in vivo activity of the glucokinase beta-cell promoter is not known, the A variant may contribute to IGT in Japanese. The polymorphism is located in a 26-base pair region of DNA which is homologous between human and rat. The high degree of conservation at this locus, along with these preliminary studies of the transcriptional activity indicate that the promoter region of the glucokinase gene may be important to human beta-cell function. Our study in this large group of Swedish diabetic patients, along with sex- and age-matched control subjects, did not reveal that the promoter variant is a risk factor for IDDM. This is further supported by our analysis of the first 207 subjects in the Swedish Childhood Diabetes Study [26] which in a simple analysis of contigency tables revealed no evidence of an association between IDDM and the glucokinase promoter polymorphism among the $0-14$-year-olds $(p=0.52)$, confirming the results of the analysis of the 15-34-year-olds.

It was recently reported that microsatellite markers in and around the glucokinase gene showed significant linkage and association to IDDM in a sib pair analysis using families with at least two affected members [5]. It is possible that these microsatellite markers are located at a distance from the beta-cell specific promoter which precludes linkage disequilibrium and detection by genetic association. In summary, our analysis does not support the hypothesis that the glucokinase 
gene beta-cell specific promoter variant is a risk factor for IDDM in the Swedish population. The possible importance of the beta-cell specific promoter polymorphism in Swedish NIDDM patients needs to be studied in subjects older than 35 years of age.

A cknowledgements. This study was supported by the National Institutes of Health (DK 42654, DK 26160, DK 17047), the University of Washington R.H. Williams Laboratory endowment, the Swedish Diabetes Association, and the Swedish Medical Research Council (19X-10408). R. L. is an ARCS student and K. L. was supported by a Howard Hughes Medical Institute summer student fellowship.

\section{* DISS I nvestigators}

H. Arnqvist, Faculty of Health Science, University of Linköping, Linköping, Sweden

G. Blohmé, Sahlgrenska University Hospital, University of Göteborg, Göteborg, Sweden

F. Lithner, Umeå University, Umeå, Sweden

B. Littorin, Lund University Hospital, Lund, Sweden

L. Nyström, Umeå University, Umeå, Sweden

B.Scherstén, Department of Community Health Sciences, Dalby/Lund, Lund University, Lund, Sweden

L. Wibell, University Hospital, Uppsala University, Sweden

J. Östman, Huddinge Hospital, Karolinska Institute, Huddinge, Sweden

G. Sundkvist, Malmö University Hospital, Malmö, Sweden

\section{References}

1. Matschinsky F, Liang Y, Kesavan P et al (1993) Glucokinase as pancreatic B cell glucose sensor and diabetes gene. J Clin Invest 92: 2092-2098

2. Magnuson MA, Shelton KD (1989) An alternate promoter in the glucokinase gene is active in the pancreatic $\beta$ cell. $\mathrm{J}$ Biol Chem 264: 15936-15942

3. Elbein SC, Hoffman M, Qin H, Chiu K, Tanizawa Y, Permutt MA (1994) Molecular screening of the glucokinase gene in familial type 2 (non-insulin-dependent) diabetes mellitus. Diabetologia 37: 182-187

4. Zouali H, Vaxillaire M, Lesage S et al (1993) Linkage analysis and molecular scanning of glucokinase gene in NIDDM families. Diabetes 42: 1238-1245

5. Rowe RE, Wapelhorst B, Bell GI, Risch N, Spielman RS, Concannon P (1995) Linkage and association between insulin-dependent diabetes mellitus (IDDM) susceptibility and markers near the glucokinase gene on chromosome 7. Nature Genetics 10: 240-242

6. Owerbach D, Gabbay KH (1996) The search for IDDM susceptibility genes. Diabetes 45: 544-550

7. Chiu KC, Province MA, Permutt MA (1992) Glucokinase gene is genetic marker for NIDDM in American blacks. Diabetes 41: 843-849

8. Chiu KC, Province MA, Dowse GK et al (1992) A genetic marker at the glucokinase gene locus for type 2 (non-insulin-dependent) diabetes mellitus in Mauritian Creoles. Diabetologia 35: 632-8

9. Noda K, Matsutani A, Tanizawa Yet al (1993) Polymorphic microsatellite repeat markers at the glucokinase gene locus are positively associated with NIDDM in Japanese. Diabetes 42: 1147-1152

10. Stone LM, Kahn SE, Fujimoto WY, Deeb S, Porte JD (1996) A variation at position - 30 of the B-cell glucokinase gene promoter is associated with reduced B-cell function in middle-aged Japanese-American men. Diabetes 45: 422428

11. Chiu KC, Go RCP, Aoki M et al (1994) Glucokinase gene in gestational diabetes mellitus: population association study and molecular scanning. Diabetologia 37: 104-110

12. Landin-Olsson M, Karlsson FA, Lernmark Å, Sundkvist G (1992) Islet cell and thyrogastric antibodies in 633 consecutive 15-34-year-old patients in the Diabetes Incidence Study in Sweden (DISS). Diabetes 41: 1022-1027

13. Blohmé G, Nyström L, Arnqvist HJ et al (1992) Male predominance of insulin-dependent diabetes mellitus in young adults: results from a 5-year prospective nationwide study of the 15-34 year age group in Sweden. Diabetologia 35: 56-62

14. Nyström L, Dahlquist G, Östman J et al (1992) Risk of developing insulin-dependent diabetes mellitus (IDDM) before 35 year of age: indications of climatological determinants for age at onset. Int J Epidemiology 21: 352-358

15. Stone LM, Kahn SE, Deeb SS, Fujimoto WY, Porte D Jr (1994) Glucokinase gene variations in Japanese-Americans with a family history of NIDDM. Diabetes Care 17: 1480 1483

16. Orita M, Iwahana H, Kanazawa H, Hayashi K, Sekiya T (1989) Detection of polymorphisms of human DNA by gene electrophoresis as single-strand conformation polymorphism. Proc Natl Acad Sci 86: 2766-2770

17. Sanjeevi CB, Lybrand TP, DeWeese C et al (1995) Polymorphic amino acid variations in HLA-DQ are associated with systematic physical property changes and occurrence of insulin-dependent diabetes mellitus. Diabetes 44: 125131

18. Kockum I, Sanjeevi CB, Eastman S, Landin-Olsson M, Dahlquist G, Lernmark $\AA$ (1995) Population analysis of protection by HLA-DR and DQ genes protection from insulin-dependent diabetes mellitus in Swedish insulin-dependent diabetes children and controls. Eur J Immunogenetics 22: 443-465

19. Grubin CE, Daniels T, Toivola B et al. (1994) A novel radioligand binding assay to determine diagnostic accuracy of isoform-specific glutamic acid decarboxylase antibodies in childhood IDDM. Diabetologia 37: 344-350

20. Falorni A, Örtqvist E, Persson B, Lernmark Å (1995) Radioimmunoassays for glutamic acid decarboxylase (GAD65) and GAD65 autoantibodies using ${ }^{35} \mathrm{~S}$ or ${ }^{3} \mathrm{H}$ recombinant human ligands. J Immunol Methods 186: 89-99

21. Metha CR, Patel NR, Gray R (1985) On computing exact confidence interval for the common odds ratio in several $2 \times 2$ contingency tables. J Amer Stat Assoc 80: 969-973

22. Fajans SS (1996) Definition and classification of diabetes including maturity-onset of the young. In: LeRoith D, Taylor SI, Olefsky JM (eds) Diabetes mellitus. Lippincott-Raven Publishers, Philadelphia, pp 251-260

23. Froguel P, Vaxillaire M, Sun F et al (1992) Close linkage of glucokinase locus on chromosome $7 p$ to early-onset noninsulin-dependent diabetes mellitus. Nature 356: 162-164

24. Laakso M, Malkki M, Kekalainen P, Kuusisto J, Mykkanen L, Deeb S (1995) Glucokinase gene variants in subjects with late-onset NIDDM and impaired glucose tolerance. Diabetes Care 18: 398-400

25. Matsutani A, Noda K, Tao T, Tanizawa Y, Kaneko T, Kaku K (1993) Variation of promoter activity of glucokinase gene in humans. Diabetes 42: 94A (Abstract)

26. Hagopian WA, Sanjeevi CB, Kockum I et al (1995) Glutamate decarboxylase-, insulin- and islet cell-antibodies and HLA typing to detect diabetes in a general populationbased study of Swedish children. J Clin Invest 95: 15051511 